Academy reform

\section{Modest changes in progress}

THis year will probably see more changes in the academy's way of doing business than there have been for several years. Among other things, steps are being taken to institute a procedure for electing the directors of research institutes and even the heads of institute laboratories.

The academy is falling into line with the Soviet government's prescription that there should be a formal retirement age for public servants. Earlier this year, for example, it agreed that members of its Praesidium should retire at 75 (roughly 14 of 40 exceed this age), but the rule will not be enforced until 1990 .

In the same pursuit of youth, the election of new members of the academy due to be held in December will this time fill more places than will be vacated by the death of academicians, bringing the number of academicians up to 250 apart from those who exceed retirement age

The electoral proposals have been duced on 1 November. stimulated by the Soviet government's plans for "democratization", and have been circulated to all institutes as a basis for discussion. The intention is that a final set of proposals should be ready for a meeting of the academy on 28 October, and that the new rules should be intro-

The draft reforms, as circulated for discussion, allow for the election of directors and laboratory chiefs every five years. Institute directors, at present nominated by the appropriate division of the academy, will in future be elected by that division from among as many candidates as there may be. Heads of laboratories will be elected by those working in the units concerned. But it is not yet clear whether the choice will rest with all the members of a laboratory's staff or merely with those who are scientifically qualified.

Similarly, it is proposed that some of the members of the scientific councils which

\section{New man in charge of academy}

Academician G.I. Marchuk, elected president of the Soviet academy by secret ballot at the end of 1986, is a vigorous man who seems to enjoy his job. His presidency of the "big" academy seems almost a continuation of his long stint as president of the Siberian Division at Novosibirsk, although he spent two years as chairman of the State Committee on Science and Technology between the two posts.

His view of the academy's contribution to the changing climate is also cheerful it should be the academy's job to identify the fields in which it already has a great deal of expertise and to push these along faster. But he also says that the changing climate should make industry more interested in the results of research, in which case there should be opportunities for the academy network to prosper.

Marchuk does not share the usual institute view that universities are a lesser kind of institution, saying that their staffs are as well qualified as those at the research institutes. The chief difficulty for the universities, he says, is that the production ministries which are the main users of university graduates in science and technology are unwilling to meet the full cost, with the result that universities in general are unable to establish themselves in research.

Marchuk is adamant that Soviet secondary education maintains higher standards than anywhere else "including the United States". Noting curriculum changes in the past decade, he says the objective now must be to strengthen the creative component of secondary education.

Marchuk is not greatly moved by the decline of interest in science and technology among young people, which he thinks "may not be altogether a bad thing". The causes, he believes, are simply that other occupations now offer higher salaries, while the hardships of the scientific life (and the interest of social issues) have inevitably changed the patterns of

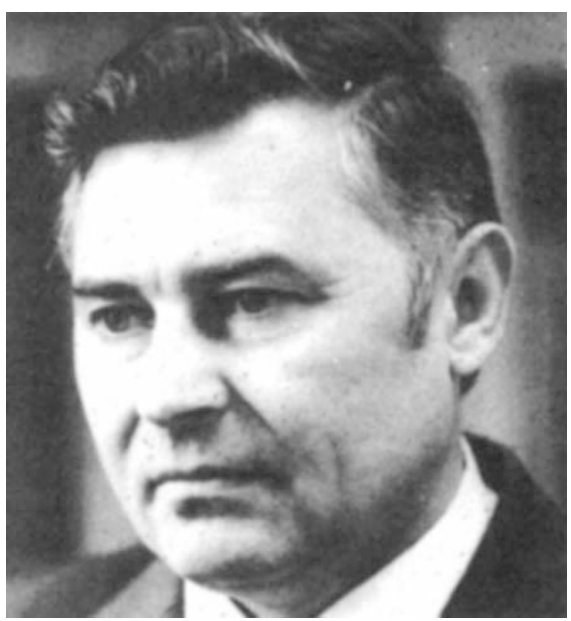

young people's choices.

Marchuk's arrival in his new office has not delighted all his fellow academicians. Some suspect the new administration's recruitment of what appears to be an alternative secretariat and are irked by the difficulty of reaching him informally by telephone. No doubt the greatest difficulty, at a time when change is almost a necessary precondition of self-respect, is to judge the pace and even the direction correctly. If anything, Marchuk may be over-cautious for the times. formally govern the research institutes should be elected by the whole staff of the institute. One of the difficulties in this set of draft proposals is that scientific councils would become even larger than they are. It is not intended that the director of an institute should cease to be the chairman of his scientific council, while the draft proposals would return the right of appointment of laboratory chiefs to the academy if one of the candidates should be an academician.

Part of the controversy surrounding the draft proposals centres on the suggestion that institute directors should be elected by the appropriate division of the academy, not by the staff of the institute. Incumbent directors seem uniformly unhappy at the notion that their tenure of office is likely to be challenged as a matter of routine every five years; curiously, there is less discontent at the likelihood that they may not be in future personally responsible for the choice of those in charge of their laboratories.

The academy says it has also begun to give some of its institutes (such as the instrumentation institute at Leningrad) the freedom to engage in commercial arrangements with outside organizations. This is consonant with a general recommendation of the government that research institutes capable of making their way in the world by means of contracts with production ministries or individual factories should be required to become self-supporting. But president Academician G.I.Marchuk says that few of the academy's institutes are in that position, and that the government is committed to the continued support of basic research.

On the common complaint by researchers that Soviet research equipment does not compare with that of rival laboratories in the West, Arnold Romanov, deputy chief scientific secretary, acknowledges that there are problems but insists that the academy is not responsible for all of them. Thus, he says, in respect of computer equipment, the Soviet Union's time-lag behind the West arises because "the importance of this field was not appreciated" early enough by other agencies of the Soviet government.

Within academy institutes, researchers complain that the personal computers now coming into service tend to be unreliable; one theoretician with four such machines for use by his group says that he must reckon that at least one will be out of service at any time, partly because of the slow speed of service and partly because spare parts are only acquired with difficulty. But the most common comment on the computer problem, especially from theoreticians, is that the shortage has been a blessing in disguise, providing mathematicians with an incentive to improve on existing computational methods. 